\title{
Gall bladder contractility in children with beta-thalassaemia
}

\author{
M.R. Nasr, ${ }^{1}$ M. Shaker, ${ }^{1}$ H. Mahdy ${ }^{1}$ and A. Hafez ${ }^{2}$
}

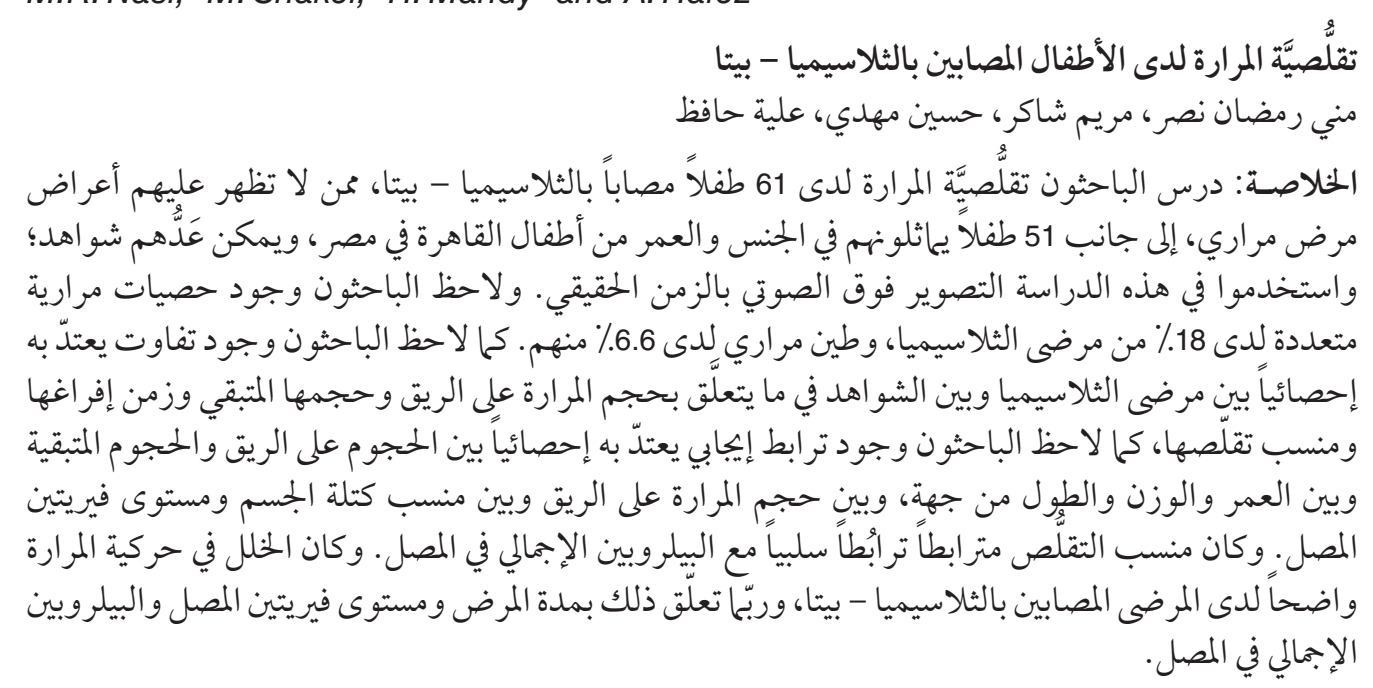

ABSTRACT We studied gall bladder contractility in 61 children with beta-thalassaemia who were asymptomatic for gall bladder disease and 51 sex- and age-matched controls in Cairo, Egypt, using real-time ultrasonography. Multiple gall bladder stones were present in $18.0 \%$ of thalassaemia patients and sludge in $6.6 \%$. There were statistically significant differences between thalassaemia patients and controls in gall bladder fasting volume, residual volume, emptying time and contraction index. There was significant positive correlation between fasting and residual volumes and age, weight and height, and between fasting volume and body mass index and serum ferritin level. Contraction index was negatively correlated with serum total bilirubin. Impaired gall bladder motility was evident in patients with betathalassaemia and it may be related to disease duration, serum ferritin and total serum bilirubin level.

\section{Contractilité de la vésicule biliaire chez les enfants atteints de bêta-thalassémie}

RÉSUMÉ Nous avons étudié la contractilité de la vésicule biliaire chez 61 enfants qui souffraient de bêta-thalassémie et ne présentaient pas de symptômes de maladie de la vésicule biliaire et chez 51 témoins appariés pour le sexe et l'âge, au Caire (Égypte), en utilisant l'ultrasonographie en temps réel. Dix-huit pour cent des sujets atteints de thalassémie présentaient des calculs vésiculaires et $6,6 \%$, une bouillie vésiculaire. On a observé des différences statistiquement significatives entre les sujets malades et les sujets témoins en ce qui concerne le volume à jeun, le volume résiduel, la durée de vidange et l'indice de contractilité de la vésicule. Il existait une corrélation positive significative entre les volumes à jeun et résiduel et l'âge, le poids et la taille, et entre le volume à jeun et l'indice de masse corporelle et le niveau de ferritine sérique. À l'inverse, il existait une corrélation négative entre l'indice de contractilité et la bilirubine sérique totale. L'altération de la motricité vésiculaire était évidente chez les sujets atteints de bêta-thalassémie et elle peut être liée à la durée de la maladie, à la ferritine sérique et à la bilirubine sérique totale.

${ }^{1}$ Department of Paediatrics; ${ }^{2}$ Chemical Pathology Laboratory, Ahmed Maher Teaching Hospital, Cairo, Egypt (Correspondence to M.R. Nasr: drmonaramad2001@yahoo.com).

Received: 08/08/06; accepted: 28/11/06

المجلة الصحية لشرق المتوسط، منظمة الصحة العالمية، المجلد الخامس عشر، العدد Y، 9 +. 


\section{Introduction}

Thalassaemias are among the most common genetic disorders in the world. Estimates suggest that $3 \%$ of the world's population carry the genes for beta-thalassaemia [1]. The disease represents a major public health problem in the Mediterranean area, the Middle East, the Indian subcontinent and the Far East [2]. In Egypt over 1000 of the annual 1.5 million babies born are expected to be affected with this disorder [3].

In beta-thalassaemia, excessive production of bilirubin from chronic haemolysis is a prerequisite for formation of pigment stones [4]. Gall-bladder dysmotility could also be a predisposing factor for formation of pigment stones or sludge in beta-thalassaemia patients [5]. Gall-bladder motility could be the clue for symptomatic or asymptomatic gallstones, as sluggish gall-bladder motility could protect the patient from pain [6], while preserved gall-bladder motility in patients with small gallstones is a risk factor for developing severe complications, especially gallstone pancreatitis which can even be fatal [7]. Ultrasonography is an accurate and useful method for studying variations in gall-bladder volume and thus emptying and refilling or the gall bladder in humans [8].

The aim of the study was to determine the gall-bladder pathology and motor function in children with beta-thalassaemia who were asymptomatic for gall-bladder disease using real-time, grey-scale ultrasound, with a view to adjusting their treatment before the appearance of symptoms.

\section{Methods}

\section{Patients and setting}

The children for this study were selected from the paediatric thalassaemia unit of Ahmed Maher teaching hospital, Cairo, Egypt. The 612-bed hospital belongs to the
General Organization of Teaching Hospitals and Institutes (GOTHI) and serves outpatients and inpatients in 21 specialties. The thalassaemia unit was inaugurated in the Department of Paediatrics in 1997 and treats thalassaemia patients referred from governorates in both Upper and Lower Egypt. Approval for the study was obtained from the medical research committee of GOTHI in 2004 before the establishment of the research ethics committee in 2006.

In all, 61 children with beta-thalassaemia were selected, 40 males and 21 females, with ages ranging between 2.5 and 18 years. All were diagnosed with beta-thalassaemia by history taking, clinical examination, complete blood picture and haemoglobin electrophoresis. They were regular attendees for blood transfusion, chelation therapy by subcutaneous desferrioxamine and follow up. Exclusion criteria were patients suffering from obesity, diabetes or liver cirrhosis. Since gall-bladder contractility may be influenced by different conditions such as obesity [9], viral hepatitis [10], liver cirrhosis [11] and diabetes mellitus [12]. We therefore chose patients who were not suffering from any of those conditions, which could be a complication of betathalassaemia.

The control group was 52 non-anaemic children with the same age and sex distribution selected from the paediatric outpatient clinic (chosen from relatives of patients with minor illness, not from the relatives of thalassaemia patients). Children with obesity, a history of diabetes or complaints of jaundice or colicky abdominal pain were excluded [13]. One child was excluded from the study when gallstones were found accidentally during the examinations.

\section{Data collection}

After taking consent from the patients and the controls and their parents, we gave them 
an appointment to come in a fasting state to give a blood sample and to have an abdominal ultrasound examination. If there were any refusals we looked for another participant fulfilling the same criteria.

All patients and controls were subjected within the same day to: complete historytaking; full clinical examination including anthropometry for body mass index (BMI); complete blood picture, serum ferritin [14], fasting blood sugar and liver function tests; and abdominal ultrasound examination while fasting 8-12 h with special emphasis on gall-bladder volume, contents and wall thickness. Gall-bladder volume $(\mathrm{mL})$ was measured by the ellipsoid method [15]. Gallstones were diagnosed by the presence of mobile high-level echoes with acoustic shadows in the gall bladder, and sludge by the presence of mildly echogenic intraluminal sediment in the absence of acoustic shadows [16]. The gall bladder wall was considered thick if it was more than $3 \mathrm{~mm}$ wide [17].

Gall-bladder volumes were monitored every 15 min over $2 \mathrm{~h}$ after ingestion of a standard test meal of about $350 \mathrm{kcal}$ which consisted of $1 \mathrm{egg}, 10 \mathrm{~g}$ butter, $30 \mathrm{~g}$ bread and $25 \mathrm{~g}$ jam or honey followed by 100 $\mathrm{mL}$ water [18]. Residual volume was the smallest volume recorded during the $2 \mathrm{~h}$. Emptying time in minutes was recorded. Contraction index was calculated from the equation according to [5]:
Contraction index $=\frac{\text { fasting volume }- \text { residual volume } \times 100}{\text { fasting volume }}$

The ultrasound equipment used was the Aloka SSD-1700 equipped with a 4-6 MHz convex probe.

\section{Statistical analysis}

Statistical analysis of the results was done using SPSS, version 10, to describe the mean, standard deviation (SD) and percentages. Student $t$-test was used to test the significance of numerical data and the chisquared test for the significance between percentages. The correlation coefficient $(r)$ was used to correlate the parameters. $P<0.05$ was considered significant.

\section{Results}

The clinical and anthropometric data of the patients and the controls showed no statistically significant difference between the 2 groups (Table 1).

The laboratory data of the patients and controls showed a statistically significant difference in haemoglobin, serum ferritin and indirect bilirubin levels $(P<0.005, P$ $<0.001$ and $P<0.01$ respectively). There was no statistically significant difference for blood sugar and direct bilirubin level or any of liver function tests (Table 2).

Gall-bladder pathology was found in $24.6 \%$ of our patients; $18.0 \%$ had gallstones

\begin{tabular}{lccl}
\hline \multicolumn{4}{l}{ Table 1 Clinical data of children with beta-thalassaemia and controls } \\
\hline Clinical data & Patients $(\boldsymbol{n}=\mathbf{6 1})$ & Controls $(\boldsymbol{n}=\mathbf{5 1})$ & Difference \\
\hline Male:female ratio & $40: 21$ & $35: 16$ & \\
Age [mean (SD) years] & $11.35(4.79)$ & $10.31(3.93)$ & $\mathrm{NS}$ \\
Age range (years) & $2.5-18$ & $2.5-17$ & \\
Height [mean (SD) cm] & $131.87(22.63)$ & $128.83(20.87)$ & $\mathrm{NS}$ \\
Weight [mean (SD) kg] & $33.22(14.91)$ & $29.17(12.53)$ & $\mathrm{NS}$ \\
Body mass index [mean (SD) $\mathrm{kg} / \mathrm{m}^{2}$ ] & $17.97(3.29)$ & $18.08(3.32)$ & $\mathrm{NS}$ \\
\hline
\end{tabular}

$S D=$ standard deviation; $N S$ = not significant.

المجلة الصحية لشرق المتوسط، منظمة الصحة العالمية، المجلد الخامس عشر، العدد ب، 9 ب. 
Table 2 Laboratory data of children with beta-thalassaemia and controls

\begin{tabular}{lccc}
\hline Laboratory data & $\begin{array}{c}\text { Patients }(\boldsymbol{n}=\mathbf{6 1}) \\
\text { Mean (SD) }\end{array}$ & $\begin{array}{c}\text { Controls }(\boldsymbol{n}=\mathbf{5 1}) \\
\text { Mean (SD) }\end{array}$ & Difference \\
\hline Haemoglobin $(\mathrm{g} / \mathrm{dL})$ & $7.03(0.84)$ & $11.56(0.91)$ & $P<0.005$ \\
Serum ferritin $(\mathrm{ng} / \mathrm{mL})$ & $1112.56(627.12)$ & $16.29(4.66)$ & $P<0.001$ \\
Fasting blood sugar $(\mathrm{mg} / \mathrm{dL})$ & $98(9.43)$ & $95(11.24)$ & $\mathrm{NS}$ \\
Serum total bilirubin $(\mathrm{mg} / \mathrm{dL})$ & $1.81(0.46)$ & $0.77(0.23)$ & $P<0.01$ \\
Direct bilirubin $(\mathrm{mg} / \mathrm{dL})$ & $0.23(0.15)$ & $0.18(0.07)$ & $\mathrm{NS}$ \\
Prothrombin time $(\mathrm{s})$ & $12.61(1.76)$ & $12.93(1.84)$ & $\mathrm{NS}$ \\
Prothrombin concentration (\%) & $89.41(10.17)$ & $85.97(12.31)$ & $\mathrm{NS}$ \\
Serum albumin $(\mathrm{g} / \mathrm{dL})$ & $4.23(0.81)$ & $4.46(1.62)$ & $\mathrm{NS}$ \\
ALT $(\mathrm{U} / \mathrm{L})$ & $42.17(13.43)$ & $39.36(9.63)$ & $\mathrm{NS}$ \\
AST (U/L) & $31.21(11.25)$ & $29.78(10.52)$ & $\mathrm{NS}$ \\
\hline ALT
\end{tabular}

$A L T=$ alanine aminotransferase $; A S T=$ aspartate aminotransferase.

$S D=$ standard deviation; $N S=$ not significant .

and $6.6 \%$ had sludge (Table 3 ). There were statistically significant differences between children with beta-thalassaemia and the controls in all the gall-bladder function parameters. Mean emptying time and contraction index were also significantly different comparing the 2 groups $(P<0.01$ and $P$ $<0.02$ respectively) (Table 3 ).

There were statistically significant positive correlations between fasting gallbladder volumes of children with betathalassaemia and age, weight, height, BMI, serum ferritin level and indirect bilirubin (Table 4). There were also statistically significant positive correlations between the gall-bladder residual volumes of the betathalassaemia children and their age, weight, height and indirect bilirubin. The contrac- tion index of our beta-thalassaemia children was significantly negatively correlated with their serum total and indirect bilirubin level (Table 4).

\section{Discussion}

Beta-thalassaemia is a disease of the chronic haemolytic state which is a predisposing factor for formation of gallstones early in life. In our study we found gallstones in $18 \%$ of the patients and sludge in $6.6 \%$. The proportion with gallstones was similar to that reported by Kalayci et al. (11.8\%) but for sludge, the proportion was much lower than in the same study (29.4\%); the small number with gallstones was attributed

\begin{tabular}{lccc}
\hline \multicolumn{4}{l}{ Table 3 Gall bladder ultrasound data in children with beta-thalassaemia and controls } \\
\hline Ultrasound data & Patients $(\boldsymbol{n}=\mathbf{6 1})$ & Controls $(\boldsymbol{n}=\mathbf{5 1})$ & Difference \\
\hline Gall bladder stones [No. (\%)] & $11(18.0)$ & $0(0.0)$ & \\
Gall bladder sludge [No. (\%)] & $4(6.6)$ & $0(0.0)$ & \\
Fasting volume [mean (SD) $\mathrm{mL}]$ & $31.20(20.66)$ & $15.36(8.94)$ & $P<0.001$ \\
Residual volume [mean (SD) mL] & $10.45(3.63)$ & $4.23(2.74)$ & $P<0.001$ \\
Emptying time [mean (SD) min] & $74.02(23.22)$ & $42.65(21.1)$ & $P<0.01$ \\
Contraction index [mean (SD)] & $57.02(12.8)$ & $73.79(12.76)$ & $P<0.02$ \\
\hline
\end{tabular}

$S D=$ standard deviation. 
Table 4 Correlation $(r)$ between gall-bladder function parameters of children with betathalassaemia and their clinical or laboratory data $(n=61)$

\begin{tabular}{lcccccccc}
\hline Variable & Fasting volume & \multicolumn{2}{c}{ Residual volume } & \multicolumn{2}{c}{ Emptying time } & \multicolumn{2}{c}{ Contraction index } \\
& $\boldsymbol{r}$ & $\boldsymbol{P}$-value & $\boldsymbol{r}$ & $\boldsymbol{P}$-value & $\boldsymbol{r}$ & $\boldsymbol{P}$-value & $\boldsymbol{r}$ & $\boldsymbol{P}$-value \\
\hline Age & 0.42 & $<0.001$ & 0.40 & $<0.001$ & -0.03 & $\mathrm{NS}$ & -0.07 & $\mathrm{NS}$ \\
Weight & 0.42 & $<0.001$ & 0.35 & $<0.01$ & -0.05 & $\mathrm{NS}$ & 0.05 & $\mathrm{NS}$ \\
Height & 0.35 & $<0.01$ & 0.29 & $<0.01$ & 0.02 & $\mathrm{NS}$ & 0.04 & $\mathrm{NS}$ \\
Body mass index & 0.36 & $<0.01$ & 0.21 & $\mathrm{NS}$ & -0.03 & $\mathrm{NS}$ & 0.13 & $\mathrm{NS}$ \\
Haemoglobin & -0.10 & $\mathrm{NS}$ & -0.03 & $\mathrm{NS}$ & -0.12 & $\mathrm{NS}$ & -0.01 & $\mathrm{NS}$ \\
Ferritin & 0.25 & $<0.05$ & 0.18 & $\mathrm{NS}$ & 0.18 & $\mathrm{NS}$ & 0.06 & $\mathrm{NS}$ \\
Total bilirubin & 0.02 & $\mathrm{NS}$ & 0.10 & $\mathrm{NS}$ & -0.08 & $\mathrm{NS}$ & -0.27 & $<0.05$ \\
Indirect bilirubin & 0.30 & $<0.05$ & 0.44 & $<0.01$ & 0.17 & $\mathrm{NS}$ & -0.26 & $<0.05$ \\
\hline
\end{tabular}

NS = not significant.

to the availability of better therapeutic modalities such as hyper-transfusion regimens and concomitant desferroxamine therapy administered early in the patient's life [5]. Galaello et al. suggested that the betathalassaemia genotype associated with Gilbert syndrome is a risk factor for development of gallstones in thalassaemia patients [19].

As regards gall-bladder function parameters, fasting gallbladder volume and residual volume in our beta-thalassaemia patients were statistically significantly higher than those of the controls. These results agree with Kalayci et al., who also found statistically significant increases in the fasting and residual volumes in their beta-thalassaemia children compared to their controls [5], and with Portincasa et al. in their adult beta-thalassaemia patients [20].

Emptying time was significantly prolonged in our patients compared with controls. This agrees with Portincasa et al., who found slightly slower emptying in thalassaemia patients than controls [20].

The contraction index was significantly decreased in our patients compared to controls, also in agreement with Kalayci et al. [5]. However, we found a statistically significant negative correlation between the contraction index of thalassaemia children and their indirect serum bilirubin levels, whereas Kalayci et al. found no relation between gall-bladder function parameters and any index of ongoing haemolysis [5]. Excess bilirubin may have a direct effect on gall bladder smooth muscle contractility to promote stasis which helps stone formation, a point which needs further research.

Our study also revealed a statistically significant positive correlation between fasting gall-bladder volume and serum ferritin level. This might be attributed to the effect of the reactive oxygen species, which have a role in impairing gall bladder emptying [21], or iron deposition in the gall-bladder wall. There was a statistically significant positive correlation between the fasting and residual gall-bladder volumes and age of our thalassaemia children, a result which might be attributed to the effect of disease duration.

We also found a statistically significant positive correlation between gall-bladder fasting volume and height, weight and BMI. Lock et al. found a weak correlation between gall-bladder fasting volume and BMI in healthy volunteers, but they did not find any correlation with age [22]. Gall-bladder

المجلة الصحية لشرق المتوسط، منظمة الصحة العالمية، المجلد الخنامس عشر، العدد ب، 9 +.. 
residual volume in our study was statistically significantly correlated positively with weight and height, which agrees with Sari et al., who found a significant positive correlation between gall-bladder fasting volume and body weight and BMI. They also found that postprandial gall-bladder motility was slower and postprandial volume was higher in obese than in non-obese women [18].

\section{Conclusions}

Ultrasound examination of the gall bladder for any pathology and volume measurement by the ellipsoid method during fasting and after oral stimulation is an easily applicable method. Contractility studies can give valuable information about the clinical course and prognosis of gall-bladder pathology.

\section{References}

1. Reith Q, Elliot V. Hemoglobin disorders. In: Kliegman RM, Jenson HB, Stanton BF, eds. Nelson textbook of pediatrics, 17th ed. Philadelphia, WB Saunders, 2004.

2. Rodgers GP. Hemoglobinopatheis: the thalassemias. In: Goldmann L, Bennett JC, eds. Cecil textbook of medicine, 21st ed. Philadelphia, WB Saunders, 2000.

3. Rady MS et al. Identification of Mediterranean beta-thalassemia mutation by reverse dot-blot in Italians and Egyptians. Hemoglobin, 1997, 21(1):59-69.

4. Heubi JE. Diseases of gallbladder in infancy, childhood, and adolescence. Chapter 16. In: Suchy FJ, Sokol RJ, Balistreri WF, eds. Liver disease in children, 2nd ed. Philadelphia, Lippincott Williams and Wilkins, 2001:343-62.

5. Kalayci AG et al. The incidence of gallbladder stones and gallbladder function in beta-thalassemic children. Acta radiologica, 1999, 40:440-3.

6. Brand B, Lerche L, Stange EF. Symptomatic or asymptomatic gallstone disease: is the gallbladder motility the clue? Hepatogastroenterology, 2002, 49(47):1208-12.

7. Venneman NG et al. Small gallstones, preserved gallbladder motility, and fast crystallization are associated with pancreatitis. Hepatology, 2005, 41(4):738-46.

8. Pallotta N. Ultrasonography in the assessment of gallbladder motor activity. Diges- tive and liver disease, 2003, 35(Suppl. 3):S67-9.

9. Sari $\mathrm{R}$ et al. Sonographic evaluation of gallbladder volume and ejection fraction in obese women without gallstones. Journal of clinical ultrasound, 2003, 31(7):352-7.

10. Portincasa $P$ et al. Changes of gallbladder and gastric dynamics in patients with acute hepatitis A. European journal of clinical investigation, 2001, 31(7):617-22.

11. Li CP et al. Evaluation of gallbladder motility in patients with liver cirrhosis: relation to gallstone formation. Digestive diseases and sciences, 2000, 45(6):1109-9.

12. Palasciano $P$ et al. Gallbladder volume and emptying in diabetics: the role of neuropathy and obesity. Journal of internal medicine, 1992, 231:123-7.

13. Schoenfield LJ et al. Asymptomatic gallstones: definition and treatment. Gastroenterology international, 1989, 2:25-9.

14. White $D$ et al. Estimation of serum ferritin by using enzyme immunoassay method. American journal of clinical pathology, 1986, 72:346-51.

15. Dodds WJ et al. Sonographic measurement of gallbladder volume. American journal of roentgenology, 1985, 145:1009-11.

16. Gallinger $S$ et al. Effects of mucous glycoprotein on nucleation time of human bile. Gastroenterology, 1985, 89:648-58. 
17. Portincasa $P$ et al. Standards for diagnosis of gastrointestinal motility disorders. Section: ultrasonography. A position statement from the Gruppo Italiano di Studio Motilità Apparato Digerente. Digestive and liver disease, 2000, 32:160-72.

18. De-Chuan $\mathrm{C}$ et al. Gallbladder contractility and volume characteristics in gallstone dyspepsia. World journal of gastroenterology, 2004, 10(5):721-4.

19. Galaello R et al. Cholelithiasis and Gilbert's syndrome in homozygous beta-thalassaemia. British journal of haematology, 2001, 115(4):926-8.
20. Portincasa $P$ et al. Impaired gallbladder motility and delayed orocecal transit contribute to pigment gallstone and biliary sludge formation in $\beta$-thalassemia major adults. World journal of gastrentrology, 2004, 10(16):2383-90.

21. Pozo MJ, Camello PJ, Mawe GM. Chemical mediators of gallbladder dysmotility. Current medicinal chemistry, 2004, 11(13):1801-12.

22. Lock $\mathrm{G}$ et al. Gallbladder motility in healthy volunteers: effect of age, gender, body mass index and hair color. Hepatogastroentrology, 2003, 50(53):1232-5.

\section{World Health Assembly}

The World Health Assembly is the decision-making body of WHO. It is attended by delegations from all WHO Member States and focuses on a specific health agenda prepared by the Executive Board. The main functions of the World Health Assembly are to determine the policies of the Organization, appoint the Director-General, supervise financial policies, and review and approve the proposed programme budget. The Health Assembly is held annually in Geneva, Switzerland.

The Sixty-second World Health Assembly will be held 18-27 May 2009 . 